\title{
MANAGEMENT OF VARIATIONS WITH THE USE OF STANDARD FORMS OF CONTRACT IN PUBLIC SEcTOR BUILDING PROJECTS IN SRI LANKA
}

\author{
SENADEERA. A. D. ${ }^{1}$, SIRIMEWAN. D. C. ${ }^{2} \&$ PERERA. B. A. K. S. ${ }^{3}$ \\ ${ }^{1}$ University of Vocational Technology, Rathmalana, Sri Lanka \\ 2,3University of Mortuwa, Moratuwa, Sri Lanka \\ 1aravindasenadeera@yahoo.com, 2dianis@uom.lk,3kanchana@uom.lk
}

\begin{abstract}
In most of the public construction projects in developing countries, a large number of 'variations' that result from the changes made to the original scopes of the projects urge the need of variation management by the parties to a contract. This study explores the ways of managing variations in public sector building projects executed in Sri Lanka with the use of Standard Forms of Contract. It applied a qualitative research approach and used a comprehensive literature review expert interviews for data collection. Manual content analysis was used to analyse the collected data. The findings reveal numerous causes of variations for which the Employer, Consultant, Contractor, or certain other factors are responsible. The research also reveals that the variations could be minimised by adopting strategies, such as the preparation of a fully detailed Employer's brief, review of the design and deployment of qualified personnel. The study proposes to modify the variation clause by adding more explanations in the Standard Form of Contract to facilitate effective variation management in Sri Lanka.
\end{abstract}

Keywords: Causes of Variation; Forms of Contract; Management Strategies; Public Sector Building; Variations.

\section{Introduction}

The construction industry in a developing country is a major contributor to the economic growth of the country, which makes use of human and physical resources while improving the economic efficiency of its processes (De Valence, 2019). The industry can afford to maintain strong links with other industries because of its large and responsive nature (Durdyev and Ismail, 2017). Hence, the contribution of the construction industry to the country's economic growth and national development is highly acknowledged, especially in developing countries (Niazi and Painting, 2017). However, changes or variations in contracts are common in modern construction projects (Onkar and Bhirud, 2015). These constant variations have an adverse impact on the public sector building projects in developing countries leading to time and cost overruns, work disruptions, conflicts and disputes. Moreover, causes of variations depend on the country, while in a particular country they depend on the sector and its associated development activities (Mhando et al., 2018).

Sri Lanka is a developing country, where the state sector plays a key role in the construction industry supported by the private sector (De Valence, 2019). Central Bank of Sri Lanka (CBSL) (2020) reported that the construction industry has contributed 6.9\% to the national Gross Domestic Product (GDP) in 2019. The construction cost of projects has increased progressively over the past decade because of increased demand, increased cost of labour and building materials (Ministry of Finance, 2017), and in particular, due to the variations occur in construction projects (Abidemi et al., 2018). Gunarathna et al. (2018) revealed that a majority of variations in construction projects in Sri Lanka occurs because of the changes made to the initial design by the Employer and the Engineer leading to conflicts in terms of time, cost and quality. Most of the government construction projects in Sri Lanka have many variations, which results in claims and disputes (Jayawardena, 2014). The majority of the claims arise from time and cost overruns; and other deficiencies in the contract (Niazi and Painting, 2017). Therefore, managing variations related costs has been a major concern in the construction industry in Sri Lanka.

In Sri Lanka, the Construction Industry Development Authority (CIDA) has published a series of Standard Bidding Documents (SBD), called 'Forms of Contracts', for the procurement of works in contracts executed in the country. They offer a range of contractual provisions that can be used to manage variations in construction projects. Previous studies focused on variation management in the construction industry in Sri Lanka have not discussed the provisions in the Standard Form of Contract for managing the variations in public sector building projects by the parties to a contract. This study, 
therefore, explores the ways of managing variations in public sector building projects in Sri Lanka by the parties to a contract by focusing on provisions in the CIDA Standard Forms of Contract. The study initially focuses on identifying causes of variations and the deficiencies of variation clause in CIDA Standard Forms of Contract. Thereafter, the study proceeds to investigate the strategies that will overcome the impact of the variations.

\section{Literature Review}

\subsection{VARIATIONS IN CONSTRUCTION PROJECTS}

The term 'variation' refers to any type of deviation from the defined scope or schedule in the initial contract (Keane et al., 2010). According to CIDA/SBD/O2 (2007), a variation may include changes to the quantities, quality, levels, positions and/or dimensions, omission or addition of any work and changes made to the sequence or timing of the execution of the Works. Since it is rarely possible to complete a project without making changes to the initial scope of works, variations have become common in construction (Sunday, 2010).

\subsection{CAUSES OF VARIATIONS}

Many causes of variations have been identified by researchers, and most of those researchers have related the causes to construction project factors such as time, cost and quality, and project stakeholders (Bello and Saka 2017). Abidemi et al. (2018), Jayawardena et al. (2014), Halwatura and Ranasinghe (2013), and Keane et al. (2010) have discussed the causes of variations under four categories: Employer-related variations, Consultant-related variations, Contractor-related variations and other causes, which are beyond the control of the parties. This study used these same categories to explore the causes of variations in public sector construction projects executed in Sri Lanka. 'Changes made to the plans or scope' by the Employer and the 'inadequate project objectives' are prominent causes among the Employer-related causes of variations (Abidemi et al., 2018). The most significant Consultant-related cause identified by Abidemi et al. (2018) and Alaryan et al. (2014) is inadequate working drawing details'. According to Mhando et al. (2018) and Onkar and Bhirud (2015), 'design discrepancies' is significant in the public sector building projects in developing countries. 'Differing site conditions' is the most prominent cause of Contractor-related variations in public sector construction projects in developing countries (Sunday, 2010, Jayawardena et al., 2014). 'Weather conditions' highly contribute to variations in developing countries (Jayawardena et al., 2014; and Abidemi et al., 2018). However, Onkar and Bhirud (2015) mentioned that 'weather conditions' and 'unforeseen problems' are equally important other causes of variations in construction projects.

\subsection{MANAGEMENT OF VARIATIONS}

Variation management in construction contracts involves identifying, initiating, instructing, approving, and valuing variations (Ministry of Finance, 2017). According to Arain and Pheng (2005), the construction process can get affected by variations and unpredictable factors depending on the performance of the parties to the contract, availability of resources, environmental conditions, the involvement of other stakeholders and contractual relations. The authors further explain that if project team members have proficient knowledge and previous experience in similar projects, proper planning could be facilitated throughout the design and construction phases to minimise and control variations and their consequences. Table 1 presents the strategies that will help to manage variations that were identified by past researchers and by the expert interviewees.

\subsection{STANDARD FORMS OF CONTRACT}

The Standard Forms of Contract set out the basic procedures and rules for managing variations (Singh, 2002). In commercial contracts, there has to be a provision to make changes to a contract in writing signed by or on behalf of both parties to the contract (Halwatura and Ranasinghe, 2013). The 
National Procurement Agency (NPA), Sri Lanka (2007) recommends procuring entities to use the series Standard Bidding Documents (SBDs) published by Construction Industry Development Authority (CIDA) as Forms of Contract with minimum changes made to the general provisions, where necessary. The CIDA/SBD/O2 (for major contracts) stipulated a few clauses as provision for variations that encompass how to initiate variation by the Engineer, the Contractor's obligations, what constitutes a variation, the process of value engineering, management of provisional sum and dealing with minor or incidental works in the contract.

\subsection{THE NEED FOR MANAGEMENT OF VARIATIONS}

Undoubtedly, managing variations is one of the most critical factors in building projects that lead directly to the successful project completion. The significant increase in labour and material prices together with the increased demand that exists for construction has increased the costs of building projects in Sri Lanka (Ministry of Finance, 2017). These causes are common in public sector building projects in developing countries (Onkar, 2015; Abidemi et al., 2018). Mhando (2018) states that a large number of variations found in these projects affect the cost and construction programmes of the projects. Arain and Pheng (2005) explained that disputes in contracts arise because of the shortcomings in the contractual provisions in the contracts. According to the Ministry of Finance (2017), variations have to be properly managed using the provisions in the conditions of contract. The rights and obligations of each party to the contract have to be properly defined in the contract to ensure a fair distribution of risks among the parties concerned. Thus, to enhance the variations management in government building projects in Sri Lanka, it is necessary to be aware of their causes to realise the impact towards project execution and the strategies that can be adopted to manage these variations.

\section{Methodology}

The research question of the study was 'How to manage the variations in public sector building projects in Sri Lanka?'. Thus, a comprehensive literature review was first done followed by expert opinion survey to collect the empirical data through qualitative means. Seventeen experts, who were well conversant with managing variations in construction projects and with more than 15 years of experience in such projects were selected using non-probability purposive sampling. The expert interviews were conducted to check initially, the validity of the literature findings on causes of variations and strategies to manage variations. Subsequently, interviewees were encouraged to present their viewpoints on causes of variations, modifications to CIDA Standard Forms of Contract and strategies to manage variations in the public sector building projects in Sri Lanka. The collected data were analysed using manual content analysis, which is appropriate for analysing qualitative data (Kumar, 2011).

\section{Findings and Analysis}

\subsection{CAUSES OF VARIATIONS IN PUBLIC SECTOR BUILDING PROJECTS IN SRI LANKA}

The interviewees were asked to comment on the causes of variations in public sector building projects that were identified from the literature and present any other causes of variations they have encountered while working in Sri Lanka (Table 1). The highlighted causes in Table 1 are the new causes identified by the interviewees as specific to Sri Lanka. All the respondents accepted, 'changes made to the plans or scope' and 'inadequate project objectives' as Employer-related causes of variations in construction projects in Sri Lanka. 
Table 1. Causes of variations in public sector building projects in Sri Lanka

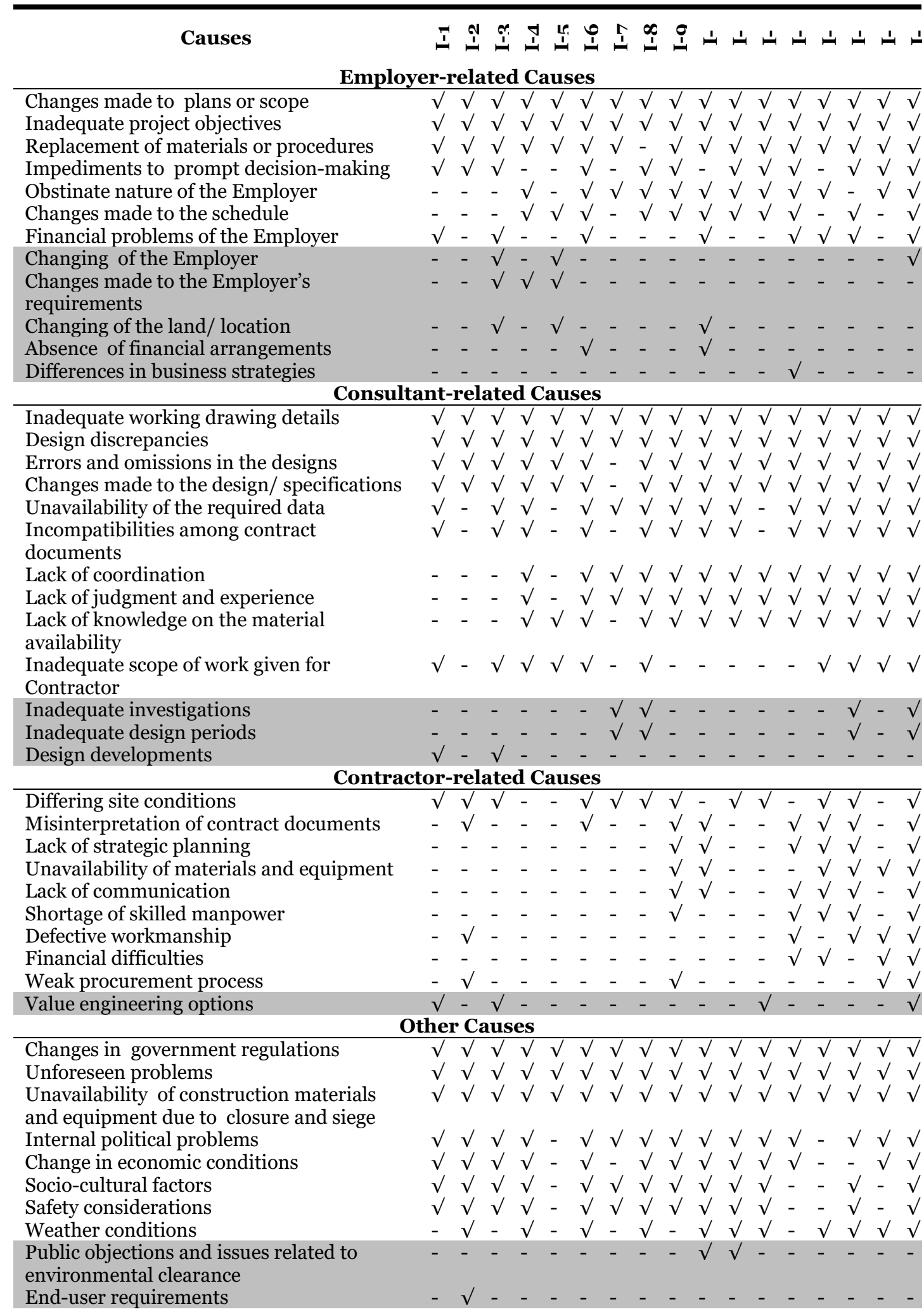

Moreover, 'Changing of the Employer' and 'changes made to the Employer's requirements' were highlighted through expert interview survey as the two most significant Employer-related causes of variations specific to the public sector building projects in Sri Lanka. 'Inadequate working drawing 
details' and 'design discrepancies' are the two most prominent Consultant-related causes as conformed by the interviewees, whereas 'inadequate investigations' and 'inadequate design periods' were the two most significant Consultant-related causes specific to Sri Lankan public sector building projects. Even though the Contractor does not contribute to variations, differing site conditions could be a cause of variations during the construction phase, as confirmed in literature and through the expert survey. Besides, the interviewees argued, value engineering options may cause variations in Sri Lanka due to lack of knowledge and experience in implementing such methods in the local context. 'Changes in government regulations', 'unforeseen problems', and 'unavailability of construction materials and equipment due to closure and siege' were the other causes confirmed by all the interviewees as the causes related to public sector building projects in Sri Lanka. Furthermore, 'public objections and issues related to environmental clearance' were found to be a major causes of variations in Sri Lanka, which is beyond the control of the parties to the contract.

\subsection{MANAGEMENT OF VARIATIONS BY THE PARTIES TO THE CONTRACT}

The interviewees were also requested to verify the strategies to address the causes of variations that were identified from the literature, are applicable in Sri Lanka and to propose any new strategies that would avoid or minimise the causes of variations in public sector building projects in Sri Lanka (Table 2). The strategies that are applicable specifically in Sri Lanka and, which are not mentioned in the literature are highlighted in Table 2. All of the interviewees confirmed that the Employer has to 'provide a fully detailed Employer's brief' that was recognised from the literature and 'define project objectives clearly at the inception stage' to minimise variations, as a specific strategy to the Sri Lankan context.

Table 2. Strategies to manage variations in public sector building projects in Sri Lanka

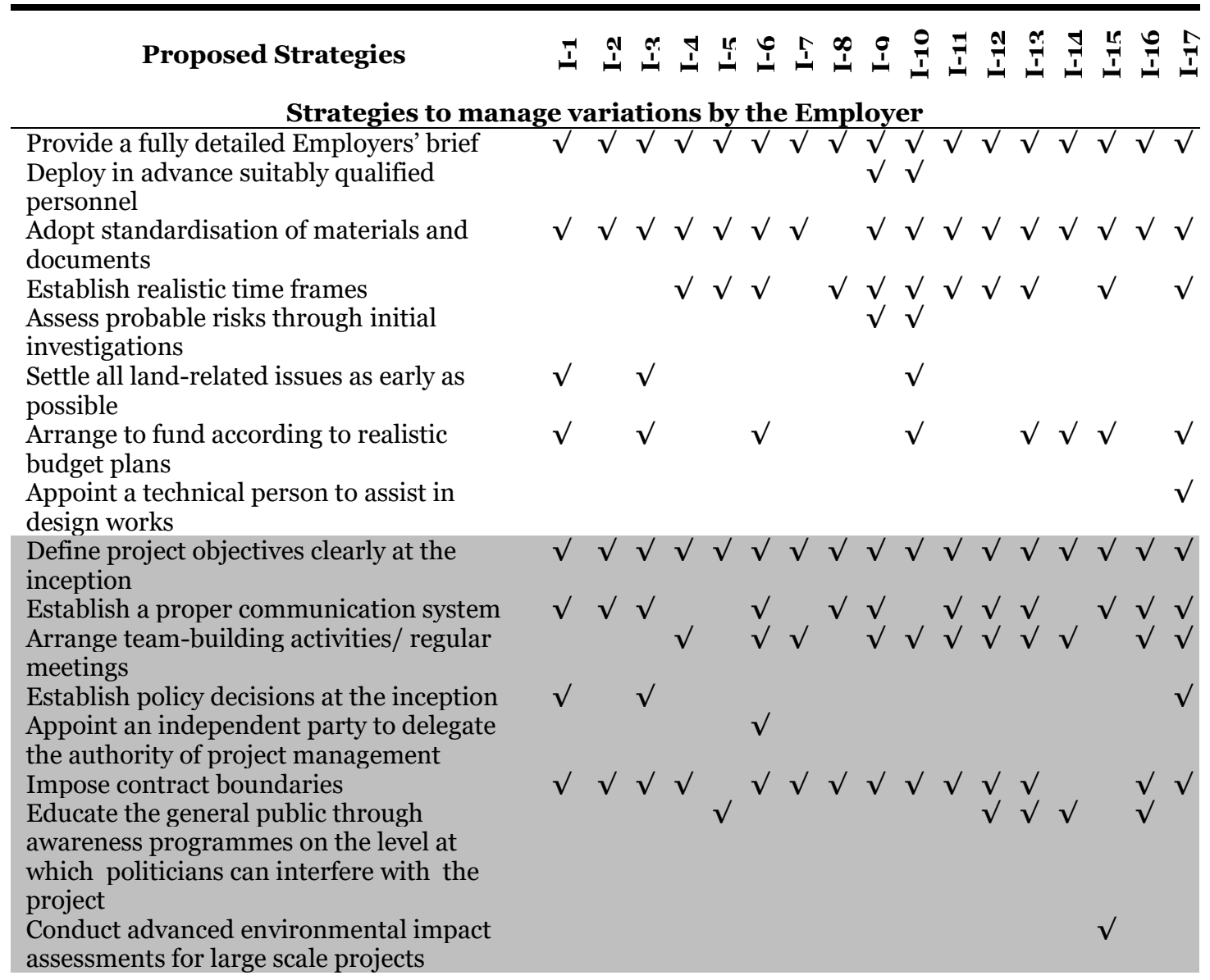


Proposed Strategies

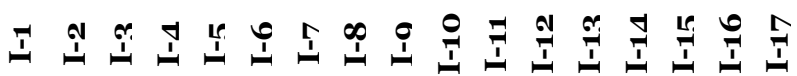

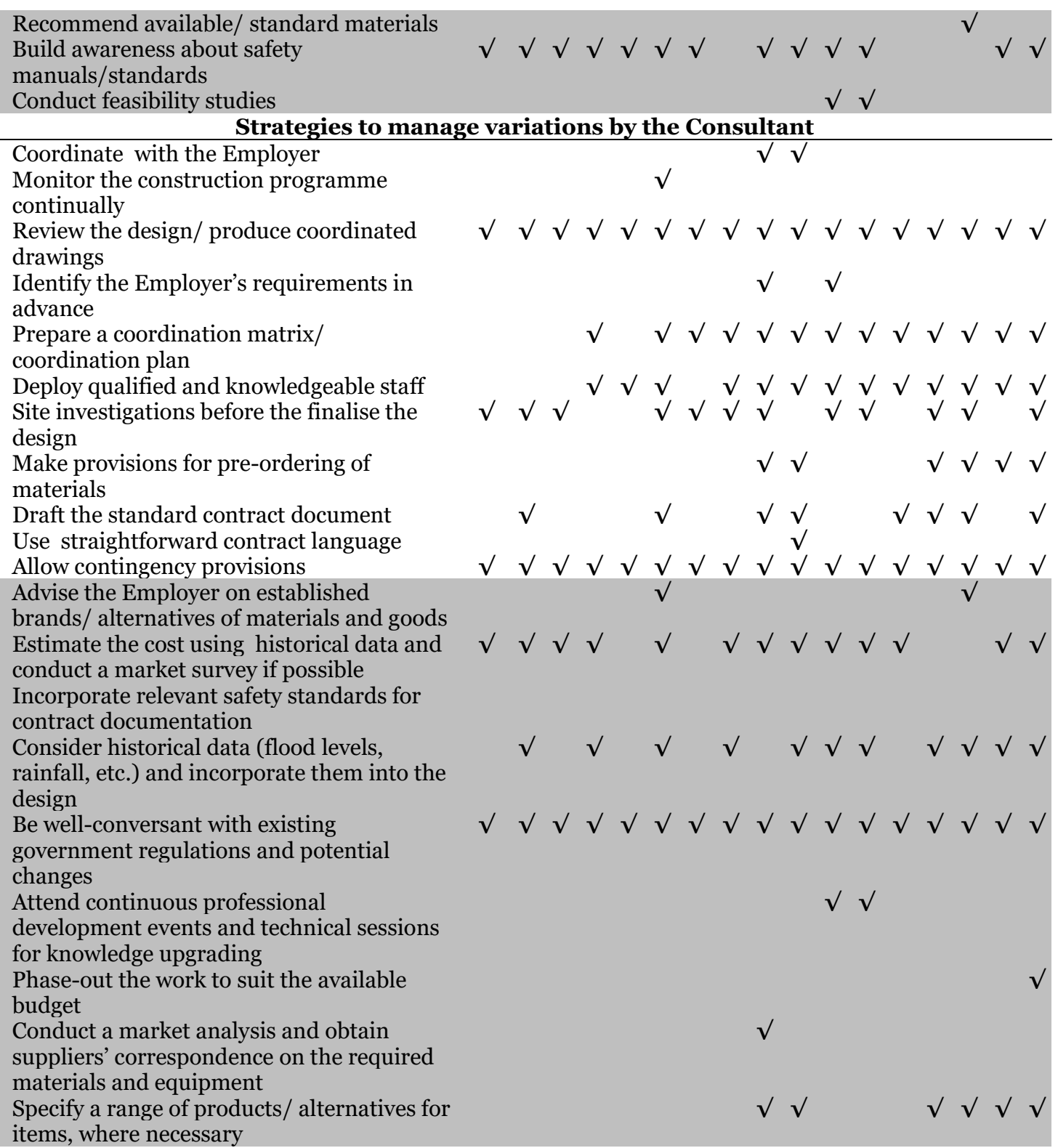

Strategies to manage variations by the Contractor

Propose value Engineering options

Update the construction programme and

inform the consequences to the other

$\sqrt{ }$

parties

Consider a risk factor at the time of

tendering

Raise 'Request for Information' as early as

possible

Deploy a competent staff

Establish a proper communication network

among the project team

Arrange manpower subcontractors

Adopt low labour incentive methods

Supervise the staff and provide training

facilities, whenever necessary

Pre-arrange funding

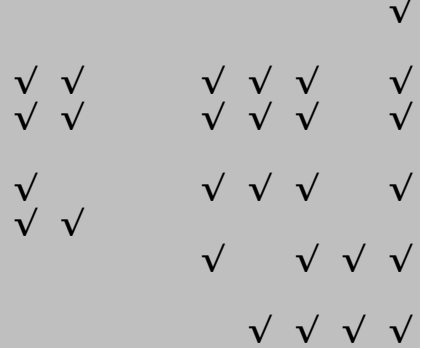


'Review the design', 'produce coordinated drawings' and 'allow contingency provisions' were the strategies proposed by the previous studies and conformed by all the respondents. In addition, 'wellconversant with the existing government regulations and potential changes' was discussed as the prominent strategy to manage variations in the Sri Lankan context that can be adopted by the Consultant. The research findings revealed less number of strategies, giving the responsibility to the Contractor in managing variations. However, the Contractor can contribute to manage variations by deploying competent staff and by establishing a proper communication network among the project team members in the Sri Lankan public sector building projects.

\subsection{MODIFICATIONS REQUIRED IN THE STANDARD FORMS OF CONTRACT TO FACILITATE VARIATION MANAGEMENT}

CIDA/SBD/O2 (2007) has provided contractual provisions to manage variations in construction projects in Sri Lanka. As indicated in Table 3, the interviewees agreed that the stipulated provisions were adequate for the time being especially in public sector building projects in Sri Lanka. They suggested that 'Sub-clause 13.4: Provisional Sums' be defined separately from 'Clause 13: Variations and Adjustments' since the two clauses refer to two different scenarios, which have to be handled separately. The Particular Conditions of Contract have to stipulate a maximum limit for the provisional sums and specify the evaluation method, the party who will design the work and when the provisional work items would commence. It was also proposed to remove 'Sub-clause 12.4: Omissions' from 'Clause 12: Measurement and Evaluation' and include it under Clause 13. The interviewees further, stated that it is necessary to have a time frame for the Engineer to approve a proposed variation relating to the scope of works, programme and costs as described in 'Sub-clause 13.3: Variation Procedure'. Then the Works relating to the variation have to commence upon a fair and reasonable approval of the same, thereby reducing the risks that the Contractor and Employer will have to face in this regard. According to Sub-clause 13.1, the Engineer may initiate the variations without obtaining the prior approval of the Employer. This could lead to the wrong use of the clause as some tend to cover-up their faults at the design stage. This shall be enlightened more as stipulated in the FIDIC Form of Contract under Sub-clause 3.1: Engineer's Duties and Authority, where the Engineer shall obtain special approval from the Employer for the works instructed under the variation clause except in an emergency, or if such variations would not increase the amount prescribed in the contract.

\section{Discussion}

The interviewees discussed that the change in specifications is a common cause of variations in public sector building projects in Sri Lanka. Mhando et al. (2018) discussed that the unavailability of detailed drawings and specifications before the commencement of the tendering stage would lead to claims and disputes at a later stage. Hence the respondents also argued, the Employer's requirements at the outset of the project. Proper coordination of the design process by the Consultant as discussed by Abidemi et al. (2018) and confirmed by the interviewees will minimise the ambiguities in the drawings and avoid missing elements in the design. Bello and Saka (1995) indicated that the appointment of an independent cost advisor is a good strategy for effective cost management starting from the inception of a project. Thus, the interviewees proposed to have an independent quantity surveyor to assist the Employer in the cost related matters of the project. The Contractor is entitled to receive payment for variations under the contract with the rate or the price determined by the Engineer. However, even when the rate of a particular item has not been reasonably determined by the Engineer, the Contractor has to carry out the work diligently without any delay, which will lead to disputes as it will be unfair for the Contractor, especially in public sector building construction projects. The interviewees stated that it is necessary to have a time frame for the Engineer to approve a proposed variation relating to the scope of works, programme and costs as described in 'Sub-clause 13.3: Variation Procedure'. Then the Works relating to the variation have to commence upon a fair and reasonable approval of the same, thereby reducing the risks that the Contractor and Employer will have to face. 
Table 3. Compatibility of Sub - Clauses in Variations and Adjustments in CIDA/SBD/o2 Conditions of Contract

\begin{tabular}{|c|c|c|c|c|c|}
\hline \multicolumn{2}{|r|}{ Clause } & \multicolumn{2}{|c|}{ Applicability } & \multirow{2}{*}{$\begin{array}{c}\text { Major } \\
\text { amendment } \\
\text { s required } \\
\text { (if }\end{array}$} & \multirow{2}{*}{$\begin{array}{c}\text { Any other proposals to } \\
\text { improve }\end{array}$} \\
\hline Sub-Clause & Particulars & Adequate & Inadequate & & \\
\hline 13.1 & $\begin{array}{l}\text { Right to Vary - } \\
\text { Initiation of variations, } \\
\text { what constitutes a } \\
\text { variation }\end{array}$ & $\begin{array}{l}\text { Agreed by all the } \\
\text { interviewees }\end{array}$ & - & - & - \\
\hline 13.2 & $\begin{array}{l}\text { Value Engineering - } \\
\text { the process of value } \\
\text { engineering }\end{array}$ & $\begin{array}{l}\text { Agreed by all the } \\
\text { interviewees }\end{array}$ & - & - & - \\
\hline $13 \cdot 3$ & $\begin{array}{l}\text { Variation } \\
\text { Procedure - the flow } \\
\text { of establishing a } \\
\text { variation order }\end{array}$ & $\begin{array}{l}\text { Agreed by all the } \\
\text { interviewees }\end{array}$ & - & - & $\begin{array}{l}\text { The works coming under } \\
\text { variations should be } \\
\text { implemented after getting } \\
\text { them approved in terms of } \\
\text { quality, time and cost } \\
\text { (I o6) }\end{array}$ \\
\hline & & & & & $\begin{array}{l}\text { Reasons for variation } \\
\text { should be indicated in the } \\
\text { variation order }\end{array}$ \\
\hline 13.4 & $\begin{array}{l}\text { Provisional Sums - } \\
\text { Executing a provisional } \\
\text { sum item by the } \\
\text { Contractor under the } \\
\text { variation procedure }\end{array}$ & $\begin{array}{l}\text { Agreed by } 16 \\
\text { interviewees }\end{array}$ & I-O5 & $\begin{array}{l}\text { Excluding } \\
\text { the clause } \\
\text { from the } \\
\text { section } \\
\text { and } \\
\text { having it } \\
\text { separately } \\
\text { (I-05) }\end{array}$ & $\begin{array}{l}\text { Some additional } \\
\text { information should be } \\
\text { provided in Contract Data } \\
\text { (I 15) }\end{array}$ \\
\hline 13.5 & $\begin{array}{l}\text { Day Works - } \\
\text { Executing a work of } \\
\text { minor or incidental } \\
\text { nature as a variation on }\end{array}$ & $\begin{array}{l}\text { Agreed by all the } \\
\text { interviewees }\end{array}$ & - & - & - \\
\hline 12.3 & $\begin{array}{l}\text { Evaluation - } \\
\text { valuation of variations }\end{array}$ & $\begin{array}{l}\text { Agreed by all the } \\
\text { interviewees }\end{array}$ & - & - & $\begin{array}{l}\text { - Adjustment of Sub-clause } \\
12.3 \text { (a) ii. } \\
\text { (I o9) }\end{array}$ \\
\hline
\end{tabular}

\section{Conclusions}

The study classifies causes of variations in public sector building projects as Employer -related; Consultant-related; Contractor-related; and other causes. The most significant Employer-related causes are 'changes made to plans or scope' and 'inadequate project objectives', whereas 'inadequate working drawing details' and 'design discrepancies' are the most prominent Consultant-related causes in public sector building projects in Sri Lanka. Even though the Contractor is not responsible for variations most of the time, 'differing site conditions' could be a cause of variations at the construction phase. 'Changes in government regulations' and 'unforeseen problems' are the noteworthy causes that come under other causes. The strategies to avoid or minimise variations has to be adopted by the party responsible for the variation while other parties also can adapt their strategies to avoid the variation. The respondents suggest several amendments to Clause 13.0: Variations and Adjustments in CIDA/SBD/O2 Conditions of Contract. They propose to combine all the relevant clauses of variations under one section; including Sub-clause 12.4: Omissions under Clause 13; and excluding Sub-clause 13.4: Provisional Sums from Clause 13. Further, the delegation of authority to the Engineer shall be rationalised in a way that no party to the contract get affected on Engineer's instructions under Subclause 3.1. The study revealed a range of causes of variations and strategies to manage variations in public sector building projects in Sri Lanka. The outcome of the study would be useful to the parties to a contract to identify the possible causes of variations in advance. Further, the strategies mentioned 
could be used to overcome the effects of variations and avoid disputes among the parties to a contract. The study can be extended by modelling a management framework for variations in construction projects in Sri Lanka.

\section{References}

Abidemi, A.M., Sakariyau, A.A. and Akeem, A.A.: 2018, Causes of variation orders and their effect on building construction projects, International Journal of Modern Management Sciences, 7(1), 1-12

Alaryan, A., Emadelbeltagi, Elshahat, A. and Dawood, M.: 2014, Causes and effects of change orders on construction projects in Kuwait, Journal of Engineering Research and Applications, 4(7), 1-8

Arain, F.M. and Low, S.P. 2007. Modelling for management of variations in building projects, Engineering, Construction and Architectural Management, 14(5), 420-433

Arain, F.M. and Pheng, L.S.: 2005, How design consultants perceive potential causes of variation orders for institutional buildings in Singapore. Architectural Engineering and Design Management, 1(3), 181-196

Bello, A.M. and Saka, A.B.: 2017. Impact of variation on project delivery in Oyo state, Nigeria, World Scientific News, 86(3), 265-282

Central Bank of Sri Lanka (CBSL). 2020, “Annual Report 2019”, Sri Lanka: CBSL

Construction Industry Development Authority (CIDA): 2007, Standard Bidding Document -Major Contracts, CIDA, Colombo.

De Valence, G.: 2019, Reframing construction within the built environment sector, Engineering, Construction and Architectural Management, 26(5), 740-745

Durdyev, S. and Ismail, S.: 2012, Role of the construction industry in economic development of Turkmenistan, Energy Education Science and Technology Part A: Energy Science and Research, 29(2), 883-890

Enshassi, A., Arain, F. and Al-Raee, S.: 2010, Causes of Variation Orders in Construction Projects, Journal of Civil Engineering and Management, 16(4), 540-551

Gunarathna, C., Yang, R. J. and Fernando, N.: 2018. Conflicts and management styles in the Sri Lankan commercial building sector, Engineering, Construction and Architectural Management, 25(2), 178-201

Halwatura, R.U. and Ranasinghe, N.P.N.P.: 2013. Causes of variation orders in road construction projects in Sri Lanka, ISRN Constr Engineering, 1

Jayawardena, N., Ramachandra, T. and Rotimi, J.: 2014, "Causes and Effects of Variations on Construction Projects" Available from: https://www.isec-society.org/ISEC_PRESS/ASEA-SEC_02/pdf/CPM-16_v4_212.pdf (accessed 15 august 2018).

Keane, P., Sertyesilisik, B. and Ross, A.D.: 2010, Variations and Change Orders on Construction Projects, Journal of Legal Affairs and Dispute Resolution in Engineering and Construction, 2(2), 89-96

Kumar, R.: 2011, Research Methodology: a step-by-step guide for beginners ( $3^{\text {rd }}$ ed.), London: SAGE Publications Ltd

Malewana, M.V.G.C.: 2009 Learning processes of construction project teams in Sri Lanka (undergraduate thesis), Sri Lanka: University of Moratuwa

Mhando, Y.B., Mlinga, R.S. and Alinaitwe, H.M.: 2018, Variation mitigation model to enhance construction performance of public building projects in Tanzania, American Journal of Civil Engineering and Architecture, 6(3), 105-118

Ministry of Finance, Government of Sri Lanka, 2017, "Guide to Project Management and Construction Management for Infrastructure Development” Available from: http: //www.treasury.gov.lk/documents/10181/369961/ Final- GPMCM.pdf. (accessed 20 august 2018)

National Procurement Agency (NPA), 2006, Procurement Manual. Sri Lanka: Department of Government Printing

Niazi, G. A., and Painting, N.: 2017, Significant factors causing cost overruns in the construction industry in Afghanistan, Procedia Engineering, 182, 510-517

Onkar, J. and Bhirud, A.N.: 2015, Review analysis on causes and effects of change orders on construction projects, International Journal on Recent and Innovation Trends Computing and Communication, 3(4), 2230-2233

Singh, H.: 2002, Engineering and construction contracts management: Law and principles. LexisNexis

Sunday, O.A.: 2010, Impact of variation orders on public construction projects. in: Egbu, C. (ed), Procs 26th Annual ARCOM Conference, Association of Researchers in Construction Management, Leeds, UK 